\title{
A NEW NETWORK OF BOTANIC GARDENS IN THE BALTIC SEA REGION
}

\author{
Bengt Rosén ${ }^{1}$ and Bengt Jonsell ${ }^{2}$
}

\begin{abstract}
The establishment of a network of botanic gardens in the countries which surround the Baltic Sea is described. The development, funding and terms of reference for the group are described. A list of members and a map showing their locations is also included.
\end{abstract}

\section{INTRODUCTION}

In 2005 the Botanic Garden in Visby on the island of Gotland, Sweden, in the middle of the Baltic Sea, celebrated its 150th anniversary. During the reception, the former regional governor of Gotland approached the Chairman of the Board of the Garden, asking whether we would be interested in creating a network of cooperation between botanic gardens in the Baltic Sea region. Since the fall of the Soviet Union and the liberation of the Baltic countries, the government of Sweden and the Swedish International Development Agency (SIDA) have been encouraging cooperation between all the countries surrounding the Baltic. The regional government of Gotland has also considered it important to develop cooperation with our neighbours on the other side of the sea. Both the regional and the local authorities considered it appropriate that Gotland, in the middle of the Baltic, should play an active and central role not only physically but also functionally in different sectors of society.

\section{THE DBW BOTANIC GARDEN IN VISBY}

The Botanic Garden in Visby is owned by the DBW Society. DBW is a non-profit society, the full name of which was a secret when it was established in 1814 and which stands for 'De Badande Wännerna' - 'The Bathing Friends'. The society is generally referred to as 'DBW'. A group of nine young men founded this society in 1814 with the aim of combining their interest in swimming in the sea, which was extremely unusual in those days, with 'doing something useful for public society'. The society still donates between 1.5 and 2 million SEK (approximately 150,000-200,000€) every year for cultural and scientific purposes and the members still have a collective swim in the sea once a year, in July.

1. Bengt Rosén PhD is Vice President of DBW Botanic Garden. Address: Bergsgatan 4, 62155 Visby, Sweden. Email: bengt.h.rosen@telia.com

2. Bengt Jonsell is Professor Emeritus and Overseer of DBW Botanic Garden. Address: Konsumvägen 20B, S-75645

Uppsala, Sweden. Email: bengt.jonsell@tele2.se 
The first action of the DBW Society was to start a free school for boys in 1815 . In 1830 the Society founded the first bank on Gotland and, as mentioned, the Botanic Garden was founded in 1855. Since 1972 the Garden has been operated by the Municipality. It is governed by a Board consisting of representatives from both the DBW Society and the Municipality of Gotland. The Garden is open all year around and entry is free of charge. It is visited by more than 300,000 visitors a year from all over the world. It has a rich collection of trees and shrubs, many of which are rare in Swedish gardens, and an attractive collection of roses and many examples of horticulturally and botanically interesting perennials (see Fig. 1). The combination of an extremely beautiful garden and a medieval town, completely surrounded by a town wall, is a wonderful attraction. Visby has been designated as a UNESCO world heritage site since 1995. This means that it is considered to be of outstanding and unique cultural value to humanity (UNESCO, 1992-2011).

\section{THE ESTABLISHMENT OF THE NETWORK}

The initiative to establish a network of botanic gardens, proposed by the regional governor in 2005, was well received by the Board. After some preparations, in late January 2008 an initial meeting was held in Visby with representatives from one botanic garden from each of the countries in the Baltic Sea region: Finland, Russia, Estonia, Latvia, Lithuania, Poland, Germany, Denmark and Sweden. For three days in JanuaryFebruary 2008 the participants discussed the initiative, decided that the network

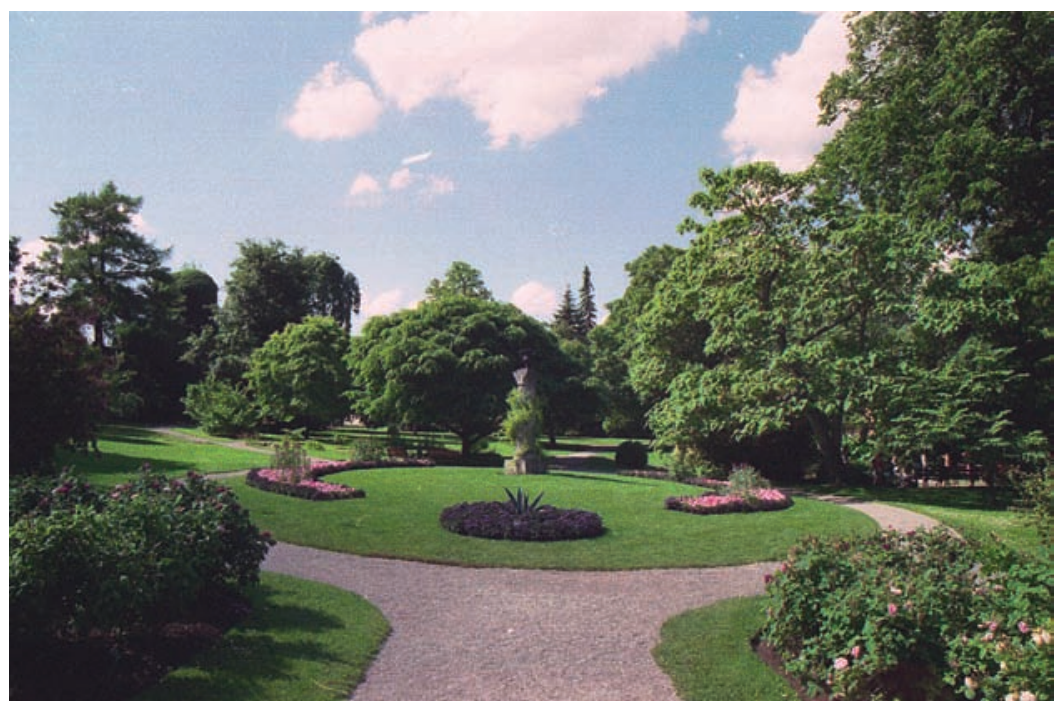

Fig. 1 The DBW Botanic Garden in Visby was founded in 1855. It is situated in the middle of the medieval town of Visby, now a UNESCO World Heritage Site. It is a relatively small botanic garden in area but receives more than 300,000 visitors a year. Photo: Bengt Rosén. 


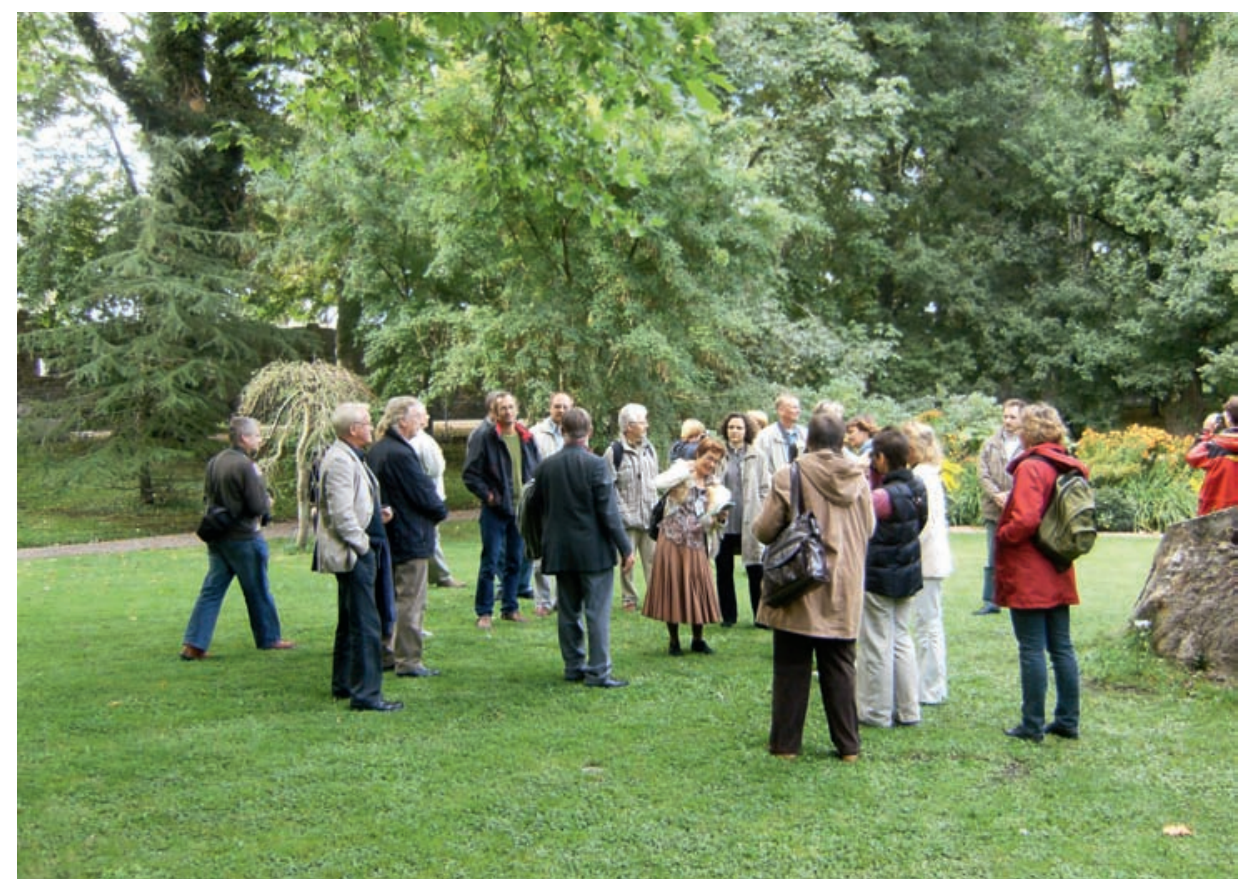

Fig. 2 The first general meeting of the Botanical Gardens in the Baltic Sea Region network was held in DBW Botanic Garden in 2008. The 35 participants decided to establish a cooperative network with general meetings once a year. Photo: Bengt Rosén.

language should be English and agreed that there were a lot of matters of common interest for future cooperation (see Fig. 2). These were:

- public arrangements, exhibitions, presentations and information

- research and science and communication of this to the general public

- conservation of wild plants, in situ and ex situ

- horticulture with special regard to public interest

- understanding of environmental problems, ecological connections and climate change

- importance of botanic gardens for health, recreation and socio-education

- development of botanic garden tourism

- documentation, botanic-genetic archives and plant material exchange

- staff exchange and internal education

- sustainability of energy and water supply and pest control in greenhouses and gardens

Beyond that the botanic gardens of the Baltic Sea region also have a common background in: 
- geography

- history

- culture

- climate

- environment/ecology

\section{FUNDING}

With this agreement three gardens from each of the nine countries around the Baltic Sea were invited to a meeting, again in Visby, in September 2008. Most of the countries proved to have three or more 'official' botanic gardens in the vicinity of the Baltic Sea, while some have only two, such as Estonia, Latvia and Denmark. From the beginning our initiative was supported by SIDA in the form of a grant of 60,000 SEK (approximately 5,500€) for the first meeting in January 2008 and another 300,000 SEK (about $27,000 €)$ for the following meeting in September. This support enabled all participants to attend without cost to themselves as SIDA had stipulated that no one should decline the invitation because of financial difficulties. At this meeting all agreed to begin cooperation. The work done and the goals achieved in 2008 were so promising that SIDA kindly granted us another 300,000 SEK spread over the three years from 2009 to 2011.

\section{PARTICIPATING GARDENS AND STEERING GROUP}

The participating gardens are as follows; the numbers correspond to the numbers on the map in Fig. 3:

1. DBW Botanic Garden, Visby, Sweden

2. Uppsala University Botanic Garden, Uppsala, Sweden

3. Bergianska trädgården, Stockholm, Sweden

4. Botanical Garden, University of Turku, Finland

5. Botanical Garden of the University of Oulu, Finland

6. Botanic Garden, Finnish Museum of Natural History, Helsinki, Finland

7. Komarov Botanical Institute (RAS), St Petersburg, Russia

8. Tallinn Botanic Garden, Tallinn, Estonia

9. Botanical Garden of the University of Tartu, Estonia

10. Botanic Garden, University of Latvia, Riga, Latvia

11. National Botanical Garden of Latvia, Salaspils, Latvia

12. Botanic Garden of Siauliai University, Siauliai, Lithuania

13. Botanical Garden of Kaunas, Vytautas Magnus University, Kaunas, Lithuania

14. Botanical Garden of Vilnius University, Vilnius, Lithuania

15. Ecological Centre for Children, Kaliningrad, Russia

16. Botanical Garden - Centre for Botanical Diversity, Polish Academy of Sciences, Warsaw, Poland 


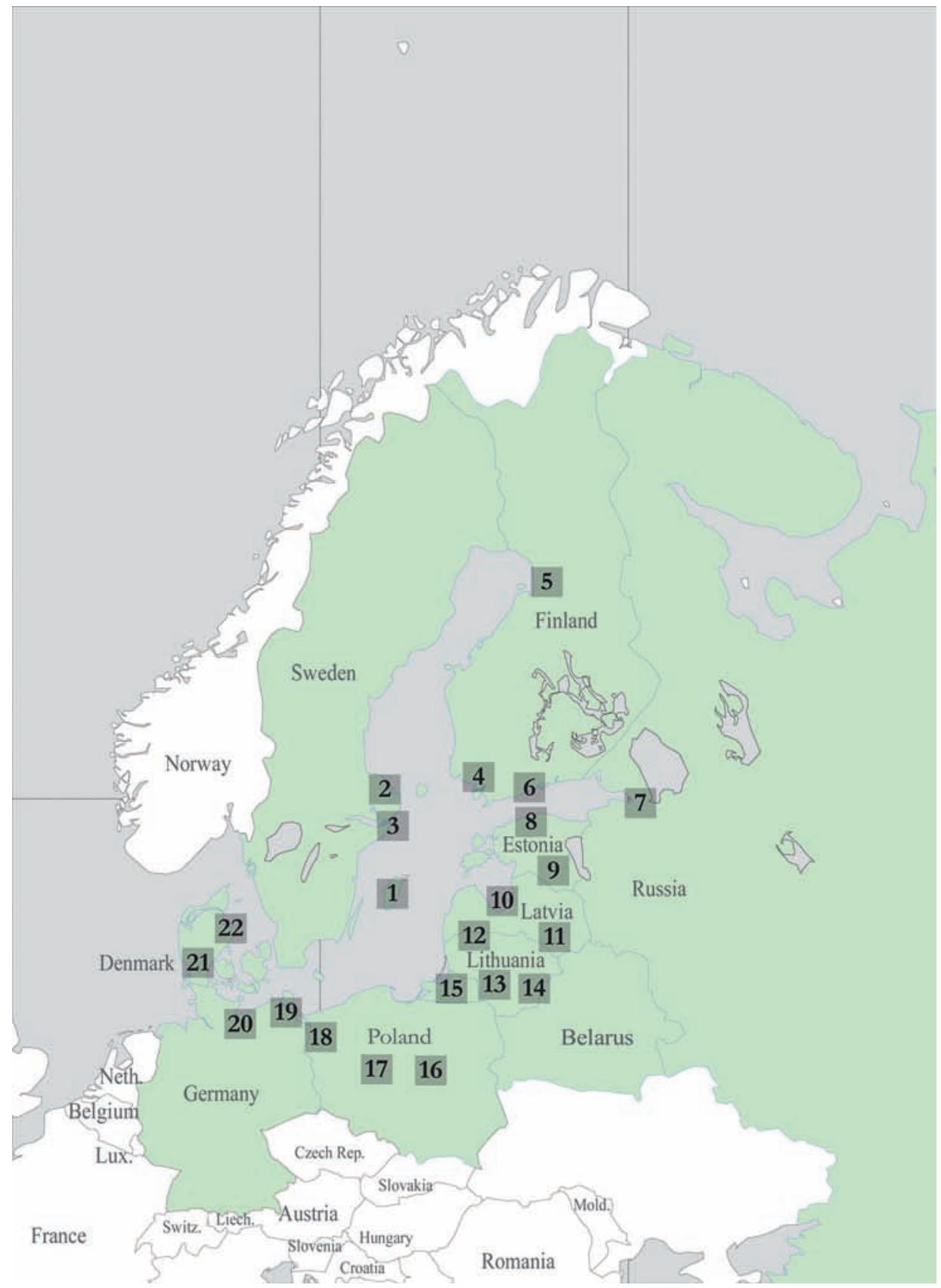

Fig. 3 Map of the Baltic Sea countries showing the botanic gardens in the network. The numbers correspond to the adjacent numbered list of institutions and gardens. Map drawn by Kerstin Price. 
17. Botanical Garden of Adam Mickiewicz University, Poznan, Poland

18. Dendrological Garden - Przelewice, Przelewice, Poland

19. Botanic Garden of the Ernst Moritz Arndt University, Greifswald, Germany

20. Botanical Garden of the University, Rostock, Germany

21. Botanic Garden of the Christian Albert University, Kiel, Germany

22. Botanic Garden, Natural History Museum of Denmark, Copenhagen, Denmark

In September 2008 a structure was agreed rather than a formal organisation for the cooperation. A steering group was formed, consisting of Professor Bengt Jonsell (1), Dr Jette Dahl Möller (22) and Dr Heiki Tamm (9). The working group already operating from Visby was entrusted to form a basic committee for practical matters such as discussions with SIDA about financial matters, producing memoranda and organising meetings. This group consists of Mr Göran Allard, Professor Bengt Jonsell, Dr Lennart Lindgren and Dr Bengt Rosén. These individuals are all from the DBW Society, which is the formal owner of the financial support from SIDA. The Regional Government of Gotland has continued to support the project through a part-time secretary. From the start we have found it essential to invite the Botanic Gardens Conservation International (BGCI) to support us with good advice from their experience of botanic garden networks from around the world. Since 2009 we have also been lucky enough to engage Dr David Rae, Director of Horticulture at the Royal Botanic Garden Edinburgh, with his vast experience of building international networks.

In September 2008 it was agreed that a second general meeting would be held in 2009. The logo of the network was designed as part of the preparations for this meeting (see Fig. 4). The logo is intended to symbolise the unifying features of the Baltic Sea for the countries that surround it and the presence of botanic gardens in these countries.

The second meeting was held in Lithuania and was hosted by Dr Audrius Skridaila and his colleagues at the Botanical Garden of Vilnius University, who presented a rich and very interesting programme (see Figs 5 \& 6). It was, for us as organisers, very

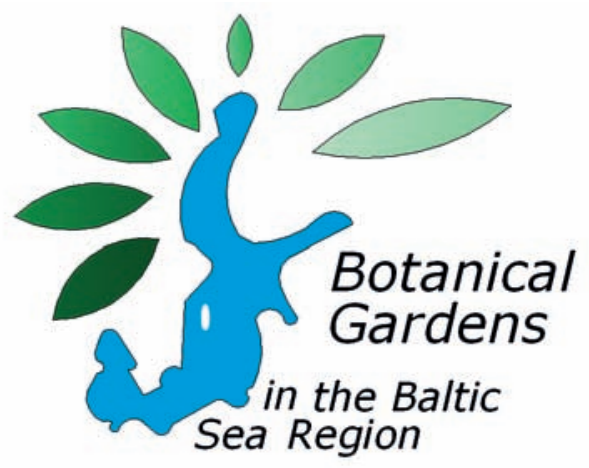

Fig. 4 Logo of the network. Designed by: Žilvinas Višinskas. 


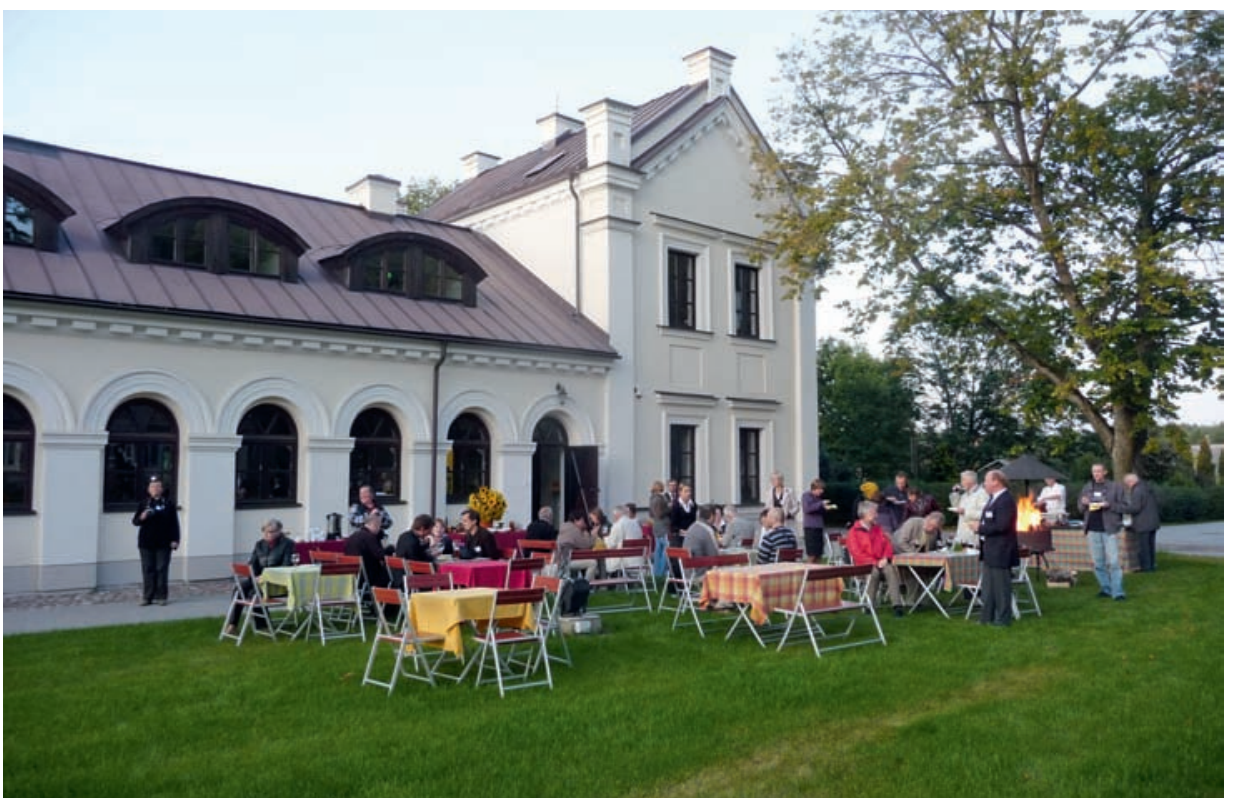

Fig. 5 Good meals in pleasant environments create a good basis for cooperation. The participants of the second meeting of the network gather outside the old stables at the Botanical Garden of Vilnius University. Photo: Bengt Rosén.

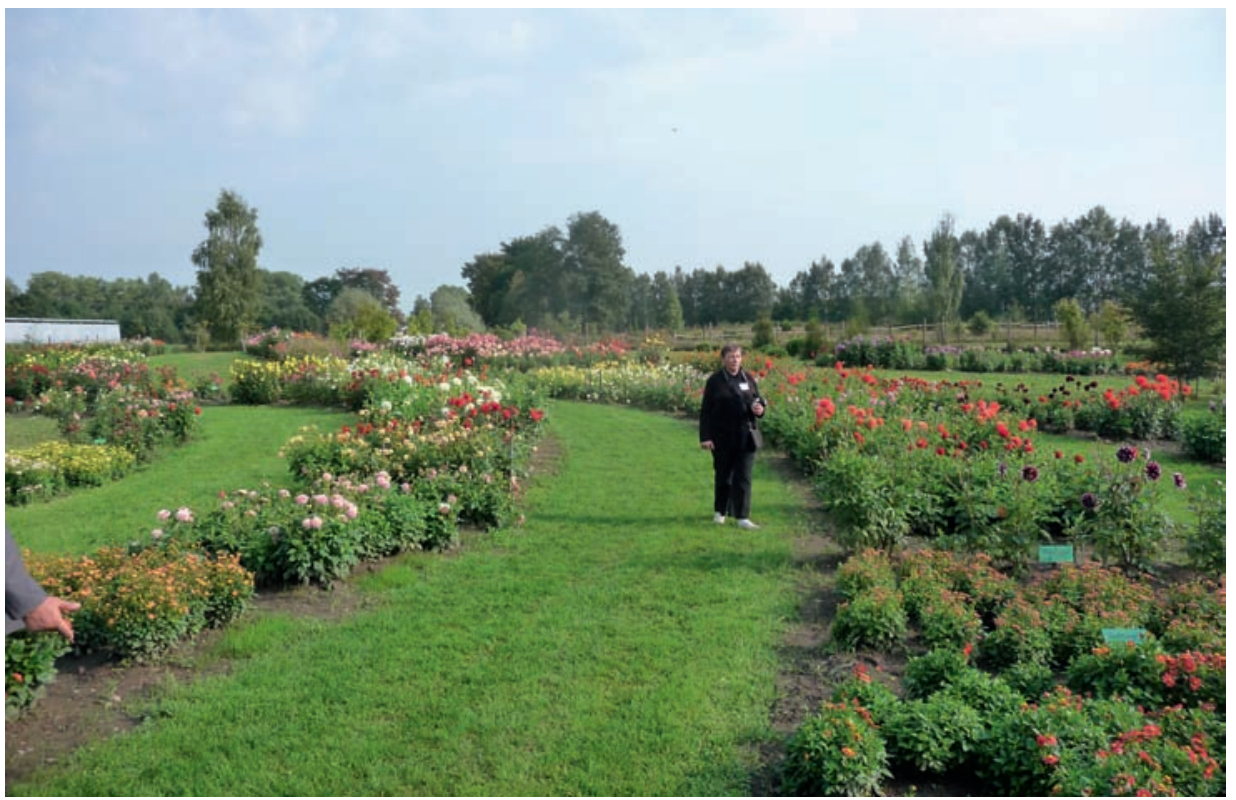

Fig. 6 The Botanical Garden of Vilnius University has plenty of room not only for botanical collections but also for art installations, for fun, for education or to stimulate thoughts. It also has collections of genetically important plant material, such as the Dahlia collection shown here. Photo: Bengt Rosén. 
encouraging to note that the majority of the participants in Vilnius also had visited the Visby conference the year before and had rejoined the network.

\section{GOALS OF THE NETWORK}

In the continuing process of cooperation we found it appropriate to limit our efforts to some directly tangible goals. These were:

- education of staff through work exchanges

- a common website, with links to all participating botanic gardens

- creation of a phenology network for monitoring climate change through some common species

- a list of endangered species grown in each garden

- all the gardens should be responsible for finding a financial model to support the constitution and objectives of the network

\section{EARLY SUCCESSES AND FURTHER DEVELOPMENT}

The next conference was held in September-October 2010 in Estonia, hosted by Heiki Tamm and his colleagues at the Botanical Garden of the University of Tartu (see Fig. 7). As in Visby and Vilnius the programme consisted of a mixture of formal lectures, discussions and visits to gardens, nearby universities and tourist sites. There was also a lot of socialising at mealtimes as well as during the conference activities. The Tartu conference ended with a visit to the Estonian capital Tallinn with its botanic garden, old town and marvellous baroque garden of Kadriorg Palace (see Fig. 8).

It was generally agreed after the Tartu meeting that our cooperation had advanced to a new level as we got to know each other better; we also found a new understanding about our different circumstances and our hopes for the future. The botanic gardens involved differ a lot in size and staff, as well as in their capacity to cope with the goals chosen for our cooperation. The DBW Botanic Garden is by far the smallest in size and staffing levels; however, it has the highest number of visitors. The Botanical Garden of Vilnius University is one of the largest, with an area of more than 250 hectares. All of the botanic gardens with the exception of DBW Botanic Garden are in some way connected to a university. The Centre for Botanical Diversity is one of the largest in terms of resources for research. DBW Botanic Garden has celebrated its 150th anniversary. The Finnish Museum of Natural History in Helsinki opened a brand new botanic garden in 2009. The Natural History Museum of Denmark in Copenhagen is completely reorganising its park.

We took home with us an invitation for next year's meeting, to Gdansk in Poland and some other interesting sites in the neighbourhood. We even received a preliminary invitation for 2012, to the Botanic Garden of Siauliai University in Lithuania. This is confirmation for us that the members of our network find it valuable and worthwhile to meet and to cooperate on common matters. 


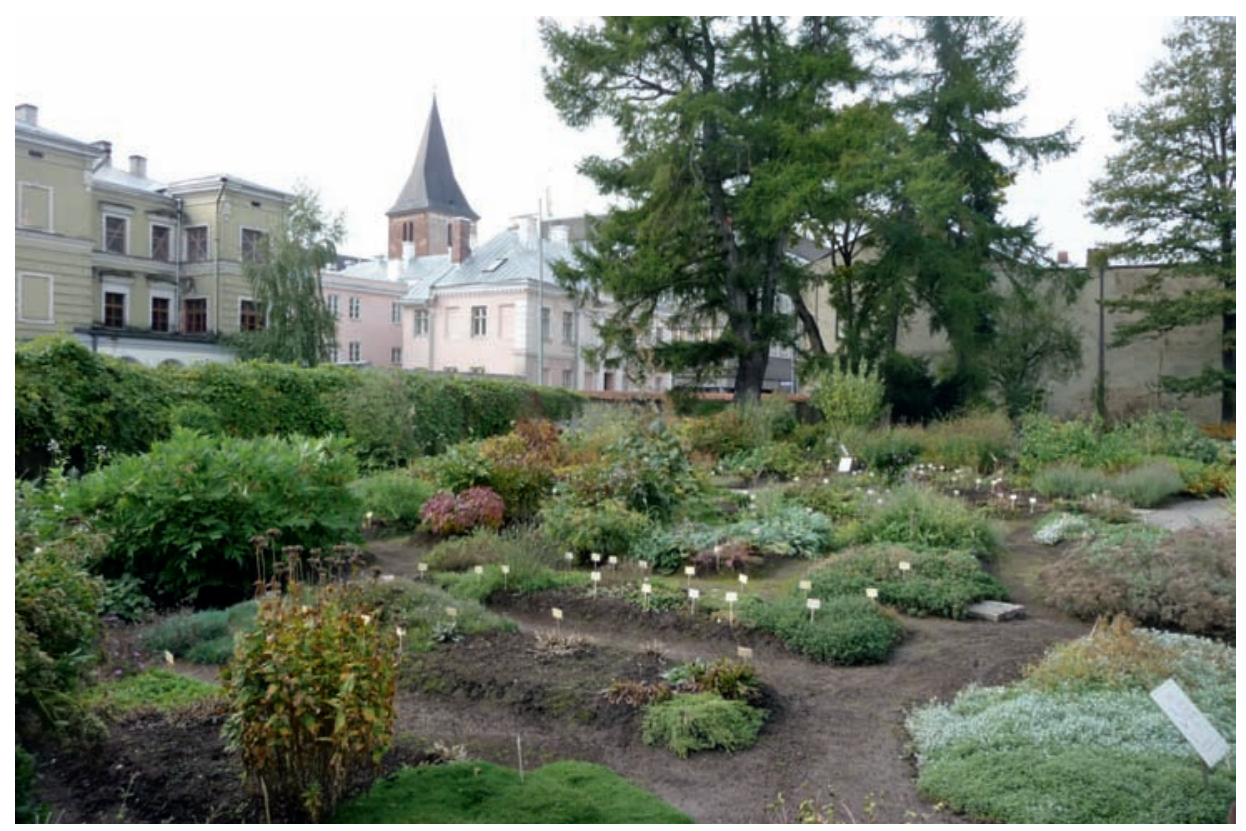

Fig. 7 The Botanical Garden in Tartu belongs to the University of Tartu, which is the oldest in Estonia, situated in the middle of the old town of Tartu. Photo: Bengt Rosén.

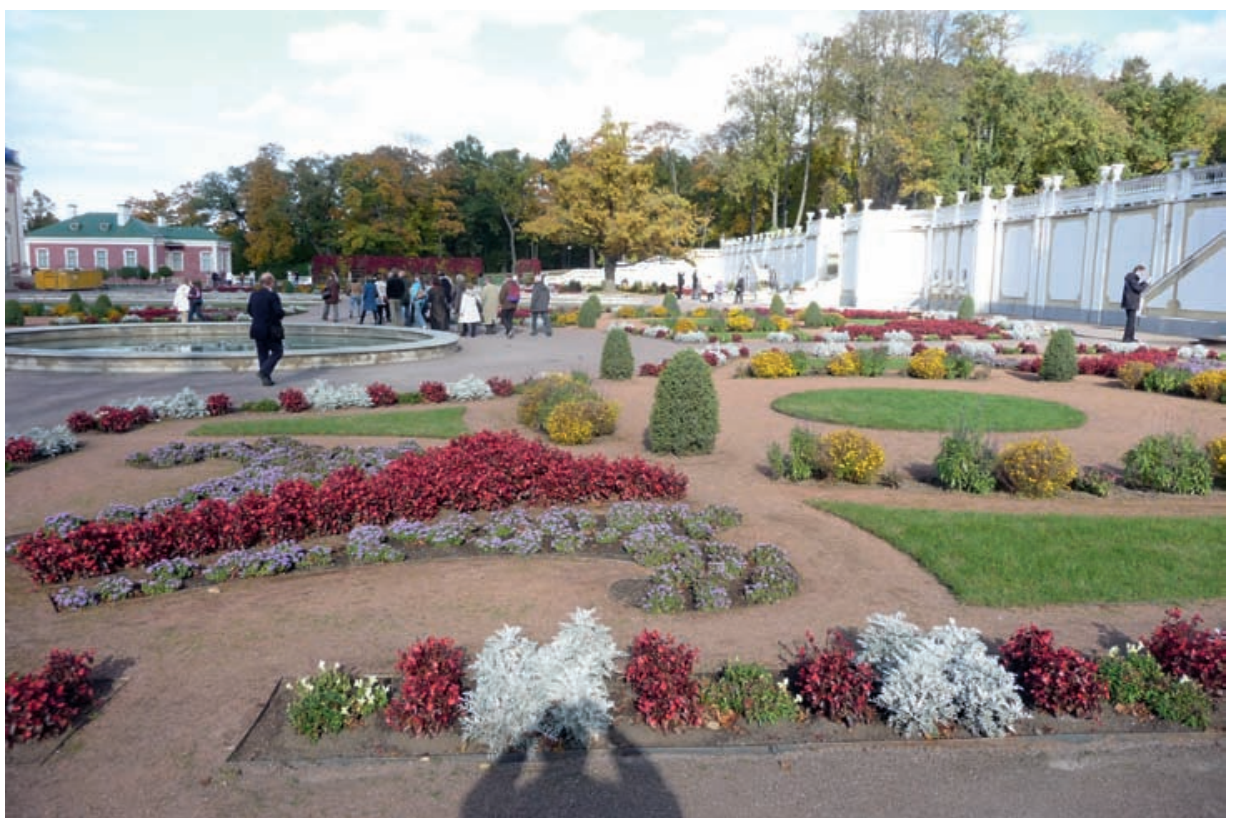

Fig. 8 The Kadriorg Palace in central Tallinn was founded in the early 18th century by the Russian tsar Peter I. It is now well known for its marvellous reconstructed baroque garden and its art gallery. Photo: Bengt Rosén. 
FUTURE GOALS AND STRATEGY

The goals to work with until 2011 were extended to include:

- completing the survey started last year by Marko Hyvärinen (then Botanical Garden of the University of Oulu, now the Finnish Museum of Natural History) of the conservation work done at the institutions.

- development of the homepage: Andrej Filimonov (Komarov Botanical Institute), Svetlana Iakovleva (Ecological Centre for Children, Kaliningrad) and Marko Hyvärinen are responsible for this. As a supplement, while the homepage is being developed, we have produced a small brochure by Göran Allard (DBW Botanic Garden) presenting the network and gardens.

- sharing ideas about education and public relations: when completed, the homepage will be used for this, and Audrius Skridaila and Peter König from the Botanic Garden of the Ernst Moritz Arndt University in Greifswald will manage this. We will also explore possibilities for producing and exchanging exhibitions.

- horticulture and staff training: botanic garden staff are different from other gardeners. The plant material they handle is extremely variable and biologically valuable. Katriina Rautala, from the Finnish Museum of Natural History Helsinki, is responsible for organising staff exchanges to promote training.

- gardens and climate change: the phenology project mentioned above continues. Magnus Lidén, from Uppsala University Botanic Garden, is leading this project.

So far action has been taken on approximately half of the five goals for the future listed above. The vision that we have for the coming years is that all five goals will have been addressed in a substantial way.

Staff from Visby Botanic Garden will continue to have a leading role in the network. We envisage that there will be cooperation between groups of staff from two to four gardens on distinct projects. These will be reported on and discussed at yearly conferences. In this way we will continuously gain deeper knowledge of the work being undertaken by the participants in the network and it is hoped that through this process we will inspire each other.

Fundraising in the future is an essential task for all the participants to consider. Superficially, cooperation between botanic gardens may seem rather exclusive, but the common goals presented at the beginning of this paper are essential not only to us in the network but to the future of mankind. For what is more important than biodiversity, nature conservation and environmental education? It is even better if these are combined with growing international cooperation and understanding.

\section{REFERENCES}

UNESCO (1992-2011). UNESCO World Heritage Centre. Available at: http://whc.unesco.org/ en/about (accessed July 2011). 